Rev. Biol. Trop., 47(1-2): 27-31, 1999

www.ucr.ac.cr www.ots.ac.cr www.ots.duke.edu

\title{
Patterns of calcium oxalate crystals in young tropical leaves: a possible role as an anti-herbivory defense
}

\author{
David S. Finley
}

Section of Plant Biology, University of California at Davis, Davis, California 95616, USA. ds finley@ hotmail.com

Received 8-IV-1998. Corrected 3-XII-1998. Accepted 7-XII-1998

\begin{abstract}
Calcium oxalate crystal formation and leaf toughness were measured and compared in five species, (Cyclanthus subpalmata, Pandanus leram, Crinum amabile, Heliconia longiflora and Guzmania zahnii) preselected for known leaf raphide production and toughness. Nine to eleven representative individuals from each species were randomly selected for the same microenvironment. The study was conducted in Las Cruces, Costa Rica. Leaves from each species were classified as two age classes: young and mature. Leaf crystal number was quantified by light microscopy. Leaf toughness was measured with a penetrometer. For all five species, the number of crystals was highest in young leaves and lowest in mature leaves. In addition, crystal formation was inversely related both to the leaf age class and to leaf toughness. It is proposed that crystal formation may be an alternative plant defense to toughness in young leaves.
\end{abstract}

Key words: Calcium oxalate, raphide, crystal, toughness.

Crystals have been found widely in both the plant and animal kingdoms as far back as the seventeenth century by the pioneers of light microscopy. Although crystal formation in plants occurs in virtually all tissues, its highest concentration may be found within internal leaf idioblasts and external trichome cells (Arnott \& Pautard 1970, Franceschi \& Horner 1980). Crystal concentration can vary considerably between species, occasionally reaching a truly enormous mass: for example, Cactus senilis has been found to have a dry weight mass of $85 \%$ crystalline calcium oxalate (Cheavin 1938).

Crystal composition is predominantly calcium oxalate $(\mathrm{CaOx})$ but can occur as at least nine other salts. Despite a unique chemical composition, $\mathrm{CaOx}$ appears in several shapes (habits) such as: raphide needles, actinic druses, prisms, rhomboids and styloid columns (Arnott \& Pautard 1970). Although the precise function of crystal formation is unclear, much attention has been focused on its role as a noxious anti-foraging device. In addition to making the host plant inedible to predators, crystals may also act as a detoxification mechanism by rendering excess reactive metabolites inert. Others have proposed roles for crystals as either simple unavoidable metabolic by-products or elegant cell regulators of osmotically active ions needed to maintain cell homeostasis (Rasmussen \& Smith 1961, Raven \& Smith 1976). They may also have a role in essential nitrogen metabolism. Finally, it is possible that crystals may serve as a passive structural support for non-lignified tissue (Franceschi \& Horner 1980). 
A widely accepted function of crystal formation is as an anti-herbivory defense (Pohl 1965, Ward et al. 1997). This study describes patterns of $\mathrm{CaOx}$ crystal accumulation and compares that to a recognized major leaf defense - toughness. Leaf crystal amount and toughness of two age classes in five tropical plants were quantified and correlated.

\section{MATERIALS AND METHODS}

Study site and plant selection: The study was conducted in the pre-montane forest reserve at the Las Cruces Biological Field Station in Coto Brus, Costa Rica. Five understory species were selected for study: Cyclanthus subpalmata $(C s)$, Pandanus leram $(\mathrm{Pl})$, Crinum amabile $(\mathrm{Ca})$, Heliconia longiflora $(H l)$, and Guzmania zahnii $(G z)$. Species known to contain leaf $\mathrm{CaOx}$ raphides were randomly selected for the same microenvironment and for a predetermined range of leaf toughness.

Leaf toughness was measured by using a penetrometer adapted from that of Feeny (Feeny 1970). The device measured the force (N) necessary to punch a $6 \mathrm{~mm}$ rod through the leaf lamina. A leaf blade was clamped between two acrylic plates, bridging a $1 \mathrm{~cm}$ hole. The penetrometer was placed over the central hole, perpendicular to the acrylic plates allowing the puncture of each leaf blade by a reproducible and measurable force. A total of eighteen measurements in three leaves for each leaf age class was obtained equaling 108 measurements per plant species.

Techniques for crystal quantification: For each of the five test species, two age classes of leaves were determined: young and mature. Age classes were assigned by measuring the leaf area $\left(\mathrm{cm}^{2}\right)$ using a LICOR (model 3200) leaf area meter. For three species ( $\mathrm{Ca}, \mathrm{Gz}$ and $\mathrm{Pl}$ ) young leaves were $\leq 25 \%$ of the surface area of the mature fully expanded leaf. For two species ( $\mathrm{Cs}$ and $\mathrm{Hl}$ ) young leaves were nearly the same size as adult leaves but were still folded. A young leaf was selected as the leaf most proximal to the shoot apical meristem. The largest fully expanded leaf immediately distal to the shoot apical meristem was designated as mature. Leaves for the five species were pre-selected for the presence of raphide crystals through a literature survey. To confirm the presence of crystals, cleared leaves were viewed between crossed polarizers in a paradermal view for characteristic crystalline birefringence. Once the presence of crystals was confirmed, soluble non-oxalate salts of calcium were dissolved in $2 \mathrm{M}$ acetic acid for 30 minutes. A modified histochemical test specific for the residual insoluble calcium oxalate crystals was then utilized (Yasue 1969). 1\% Triton X-100 was included as a modification of the initial step of the procedure. The crystals were stained brown allowing subsequent visualization of calcium oxalate without polarizers.

Quantitative crystal analysis was determined by first excising the midrib and/or major veins of each leaf. A leaf from each age class from nine to eleven representative plants was then cut into $2 \mathrm{~mm}^{2}$ or $5 \mathrm{~mm}^{2}$ sections and 24 leaf squares were randomly selected for analysis. Selected sections were cleared by heating at $85^{\circ} \mathrm{C}$ in $85 \%$ lactic acid for 20 minutes to 4 hours. Crystal counts for each section were determined by counting the crystals per field of view (10X) in the upper left corner of each leaf square. The mean crystal count per field of view was then calculated for each species. Statistical significance was computed by the one-sided Student's t-test.

\section{RESULTS}

All five species showed a higher crystal count in the young leaves than in their mature counterparts (Table 1). In two species (Cs and $H l)$ the difference in the mean crystal count between the two age classes was significant $(p$ $<0.04)$. In addition, the difference in a third species, $C a$, nearly achieved significance $(p=$ 
0.096). Two species ( $P l$ and $G z$ ) did not show a significant difference. $\mathrm{Hl}$ showed the largest difference, a $44 \%$ decrease in the crystal count of its mature leaves, whereas $C s$ decreased $32 \%$. Even $\mathrm{Ca}$ showed a decrease of $11.4 \%$, although this was not statistically significant.

TABLE 1

Mean crystal counts

Species

Mean Cristals Number/Field

\begin{tabular}{lcrl} 
& \multicolumn{1}{c}{ Young } & Mature & $\mathrm{p}$ \\
& & & \\
C. subpalmata & $7.59 \pm 1.03^{*}$ & $5.15 \pm 0.88$ & 0.034 \\
P. leram & $7.77 \pm 2.03$ & $6.06 \pm 0.69$ & 0.59 \\
C. amabile & $23.42 \pm 3.70$ & $20.81 \pm 0.58$ & 0.096 \\
H. longiflora & $44.98 \pm 2.31$ & $25.19 \pm 1.96$ & 0.001 \\
G. zahnii & $5.63 \pm 1.28$ & $3.74 \pm 0.59$ & 0.22
\end{tabular}

$*$ All values indicate mean \pm SEM

For each species, toughness (N) was highest in the mature leaves and lowest in the younger leaves (Table 2). The mean toughness difference between the two age classes was significant for all five species. The young leaves of $C s$ had the highest toughness value of $16 \mathrm{mN}$ and $\mathrm{Hl}$ had the lowest value of $3 \mathrm{mN}$.

TABLE 2

Mean toughness values for young and mature leaves

Species

Mean Toughness (mM)

\begin{tabular}{lrrr} 
& Young & Mature & \multicolumn{1}{c}{$\mathrm{p}$} \\
& & & \\
C. subpalmata & $16 \pm 0.7^{*}$ & $22 \pm 2.5$ & 0.001 \\
P. leram & $15 \pm 0.4$ & $19 \pm 1.4$ & $<0.001$ \\
C. amabile & $7 \pm 0.7$ & $11 \pm 0.7$ & 0.002 \\
H. longiflora & $3 \pm 0.1$ & $5 \pm 0.5$ & $<0.001$ \\
G. zahnii & $5 \pm 0.2$ & $9 \pm 0.2$ & $<0.001$
\end{tabular}

*All values indicate mean \pm SEM

Fig.1 shows the scattergram for the mean crystal counts versus toughness in all five species for both leaf age classes. The crystal count is inversely correlated to toughness for each of the individual species. Thus, for each species, as the leaf ages (by age class) from young to mature, its respective crystal count decreases and its toughness increases.

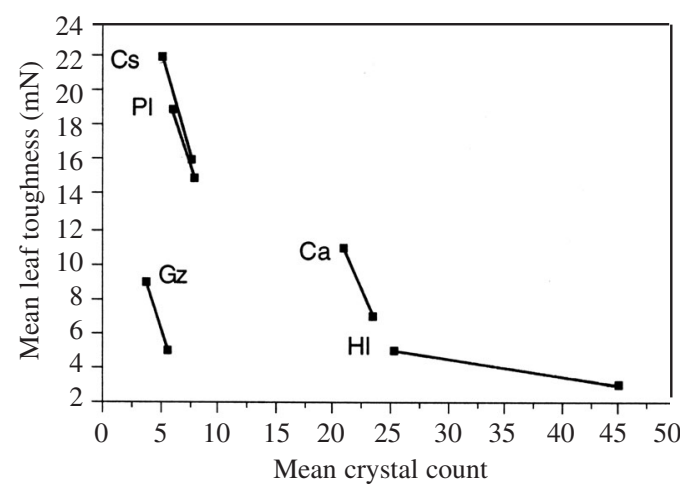

Fig. 1. Correlation of leaf toughness and crystal count.

\section{DISCUSSION}

Although crystalline function is not fully established, most attention has been focused upon an intracellular role for the crystals' components, $\mathrm{Ca}^{2+}$ and oxalate, rather than the crystal, itself, as a defense to herbivory. $\mathrm{Ca}^{2+}$ has been identified as an intracellular signal, an intra-membrane transducer and a structural protein component (Manery 1966, Arnott \& Pautard 1970). However, these functions can account for only a small proportion of total plant calcium. Metabolic needs can be met by a cytosolic $\mathrm{Ca}^{2+}$ concentration of as little as $100-200 \mathrm{nM}$, yet total plant calcium is typically found as crystals in amounts of milligrams/gram of dry tissue (Arnott \& Pautard 1970, Franceschi \& Horner 1980, Gilroy et al. 1993). Thus, even if crystalline calcium is a major $\mathrm{Ca}^{2+}$ reservoir, crystals themselves must serve some other function than just cellular metabolism alone.

Oxalate, the anionic component of most crystals, has also received attention as a driver of crystal formation. Oxalate is known largely as a toxic end product of metabolism and $\mathrm{CaOx}$ crystal formation could serve as its major form of excretion (Raven \& Smith 1976). Whether or not $\mathrm{Ca}^{2+}$ absorption is secondary to oxalate production or the reverse is controversial. It is unclear if the primary function of crystals is the facilitation of oxalate excretion (Arnott \& Pautard 1970). 
Despite these uncertainties, it is likely that macro amounts of crystal formation (typically grams) serves not only as a metabolic endproduct but also as a dynamic plant defense. There are several supportive lines of evidence: first, there is data that crystal habit is under direct genetic control. This concept is derived from physical agents that can both damage cellular DNA and RNA (such as UV and alpha irradiation) and induce changes in crystal habit presumably through alterations in habitcontrolling genes (Nadson \& RochlineGleichgerwicht 1928, Beibl 1940). Second, is the interesting finding of crystalline barbs and grooves (Sakai \& Jones 1972). Such extension structures and their associated microtubular organelles are inconsistent with the notion of crystals as simple excretory precipitates (Arnott \& Pautard 1970).

Although the data presented here only address a role for the quantity of total leaf raphides and did not examine any individual crystalline structures such as emergences, both types of observations are consistent with the notion of crystals as a defense to predation. Barbed crystal projections can serve as a deterrent to foraging by irritating the mucosa of predatory animals (Pohl 1965, Ward et al.1997). Thurston has found that Tragia ramosa and $T$. saxicola (one of four stinging plant taxa) have developed specialized stinging hair projections (emergences) which force the $\mathrm{CaOx}$ crystal through a skin puncture in order to inject toxin (Thurston 1976). These raphides contain longitudinal grooves which may serve as a channel for an unidentified protein toxin (Sakai \& Jones 1972). Similarly, even minor contact with the noxious juice of three species of Liliaceae can also cause severe human skin and mucosal irritation. This property is attributed to their high concentration of giant raphides (Pohl 1965).

Despite the above, the relative importance of crystals to plant defense is arguable. Coley notes that in mature leaves, it is toughness that is the most effective defense. She comments that rates of herbivory are 5-25 times higher in young tropical leaves than mature leaves
(Coley \& Barone 1996). This finding is attributed to a lack of toughness in immature leaves as compared to the adult leaves. If the purpose of crystal formation is primarily defensive, then the greatest crystal number should occur in the younger vulnerable leaves because they are the most nutritious and the lowest in toughness. Thus, if crystal formation serves as a complementary defense to toughness, then crystal density $\left(\# / \mathrm{cm}^{2}\right)$ should be inversely related to leaf toughness. Fig.1 shows the plot of the crystal count versus toughness, supporting this concept for all five species studied.

Even though these data support toughness as a leaf defense parameter, the concept of toughness, itself, suffers from a lack of a clear definition. Toughness is a generic quality due to an undefined and variable mix of its component cellulose, hemicellulose, pectins, and lignins. The relative contribution of each of the toughness components to the actual anti-predation defense has not been measured. As a result, any toughness value only approximates a species' actual resistance to herbivory. It is assumed that all four known components contribute similarly to herbivory resistance. It is possible, however, that pectin or cellulose may confer an equal toughness value and yet differ in their respective defensive efficiency. If so, the relationship between crystal formation and toughness to leaf defense may be considerably more complex than the simple inverse complement presented here.

\section{RESUMEN}

Se comparó cristales de oxalato de calcio y la dureza de la hoja en cinco especies, (Cyclanthus subpalmata, Pandanus leram, Crinum amabile, Heliconia longiflora, y Guzmania zahnii), pre-seleccionadas por tener ráfidos, clasificando las hojas como jóvenes y viejas. Se contó los cristales por microscopía de luz. La dureza de la hoja fue medida con un penetrómetro. En todas los especies, la cantidad de cristal fue mayor en hojas jóvenes y la formación estuvo inversamente relacionada con edad y dureza de la hoja. La formación de cristales puede ser una defensa alternativa a la dureza de las hojas jóvenes. 


\section{REFERENCES}

Arnott, J.H. \& F.G.E. Pautard. 1970. Calicification in plants, p. 375-446. In: H. Schraer (ed.) Biological calcification: cellular and molecular aspects. Appleton-Century-Crofts, New York.

Biebl, R. 1940. Weitere Untersuchungen uber die Wirkung der a Strahlen auf die Pflanzenzelle. Protoplasma 35 187-236.

Cheavin,W.H.S. 1938. The crystals and cystoliths found in plant cells. Part 1. Crystals. Microscope 2: 155-158.

Coley, P.D. \& J.A. Barone.1996. Herbivory and plant defenses in tropical forests. Ann. Rev. Ecol. Syst. 27: 305-35.

Feeny, P. 1970. Seasonal changes in oak leaf tannins and nutrients as a cause of spring feeding by winter moth caterpillars. Ecology 51: 565-581

Franceschi, V.R. \& H.T. Horner Jr. Oct-Dec, 1980. Calcium oxalate crystals in plants. Bot. Rev. 46: 361-427.

Gilroy, S. \& P. C. Bethke. 1993. Calcium homeostasis in plants. J. Cell Sci. 106: 453-462.

Manery, J.F. 1966. Effects of $\mathrm{Ca}^{2+}$ ions on membranes. Fed. Proc. 25: 1804-1810.

Nadson, G. \& B. Rochline-Gleichgerwicht. 1928. Apparition des cristaux d'oxalate de calcium dans les cellules vegetales sous l'influence de la radiation ultra violette. Compt. Rend. Soc. Biol. 98: 363-65.

Pohl, R.W. 1965. Contact dermatitis from the juice of Ornithogalum caudatum. Toxicon 3: 167-168.

Rasmussen, G.K. \& P.F. Smith, 1961. Effects of calcium, potassium and magnesium on oxalic, malic and citric acid content of Valencia orange leaf tissue. Plant Physiol. 36: 99-101.

Raven J.A. \& F.A. Smith. 1976. Nitrogen assimilation and transport in vascular land plants in relation to intracellular $\mathrm{pH}$ regulation. New Phytol. 76: 415431.

Sakai, W.S. \& R.C. Jones. 1972. Raphides with barbs and grooves in Anthosoma sagittifolium (Araceae). Science 178: 324-325.

Thurston, E.L. 1976. Morphology, fine structure and ontogeny of the stinging emergence of Tragia ramosa and T. saxicola (Euphorbiaceae). Am. J. Bot. 63: 710-718.

Ward, D., \& M. Spiegel. 1997. Gazelle herbivory and interpopulation differences in calcium oxalate content of leaves of a desert lily. J. Chem. Ecol. 23: 333-346.

Yasue, T. 1969, Histochemical identification of calcium oxalate. Acta Histochem. Cytochemistry 2: 83-95. 